\title{
TRAFFIC SOIL COMPACTION OF AN OXISOL RELATED TO SOYBEAN DEVELOPMENT AND YIELD
}

\author{
Amauri Nelson Beutler ${ }^{1 *}$; José Frederico Centurion ${ }^{1}$; Maria Aparecida Pessoa da Cruz \\ Centurion ${ }^{2}$; Onã da Silva Freddi ${ }^{3}$ : Eurico Lucas de Sousa Neto ${ }^{4}$; Cristian Luarte Leonel ${ }^{3}$; \\ Álvaro Pires da Silva ${ }^{5}$ \\ ${ }^{l}$ UNESP/FCAV - Depto. de Solos e Adubos, Rod. Prof. Paulo Donato Castellane, s/n - 14884-900 - Jaboticabal, \\ $S P$ - Brasil. \\ ${ }^{2} U N E S P / F C A V$ - Depto. de Produção Vegetal. \\ ${ }^{3}$ UNESP/FCAV - Programa de Pós-Graduação em Produção Vegetal. \\ ${ }^{4}$ UNESP/FCAV - Programa de Pós-Graduação em Ciência do Solo. \\ USP/ESALQ - Depto. de Ciência do Solo, C.P. 09 - 13418-900 - Piracicaba, SP - Brasil. \\ *Corresponding author<amaurib@yahoo.com.br>
}

\begin{abstract}
Excessive traffic on the soil may affect soybean development. This research was carried out to evaluate soybean root development and grain yield under compacted soil, in an Oxisol. The following traffic treatments were used: $\mathrm{T}_{0}=$ no traffic; $\mathrm{T}_{1^{*}}=1$ passage of a $4 \mathrm{t}$ tractor; and, $\mathrm{T}_{1}, \mathrm{~T}_{2}, \mathrm{~T}_{4}$ and $\mathrm{T}_{6}$, respectively for $1,2,4$ and 6 passages of an $11 \mathrm{t}$ tractor on the same location, each besides the other. After compaction, soybean [Glycine $\max \mathrm{cv}$. MG/BR 46 (Conquista)] was cultivated. The experiment was arranged in a completely randomized design, with six compaction levels and four replicates (plots of $9.0 \mathrm{~m}^{2}$ ). Undisturbed soil samples were collected in the layers $0.03-0.06,0.08-0.11$, 0.15-0.18 and $0.22-0.25 \mathrm{~m}$, for physical analyses. Root analyses were performed at layers of $0.0-0.10$, 0.10-0.15 and 0.20-0.25 m. Soil compaction decreased deep root development and did not affect root amount, but its distribution. Yield decreased at the penetration resistance of $2.33 \mathrm{MPa}$ or higher, and soil bulk density of $1.51 \mathrm{Mg} \mathrm{m}^{-3}$ or higher.
\end{abstract}

Key words: Glycine max, machine traffic, bulk density, penetration resistance

\section{COMPACTAÇÃO DE UM LATOSSOLO DEVIDO AO TRÁFEGO RELACIONADO AO DESENVOLVIMENTO E PRODUTIVIDADE DE SOJA}

\begin{abstract}
RESUMO: O tráfego excessivo de máquinas sobre o solo pode prejudicar o desenvolvimento da cultura da soja. Assim, o objetivo deste estudo foi avaliar o desenvolvimento radicular e a produtividade da soja em função da compactação. O experimento foi realizado em Latossolo Vermelho de textura média. Os tratamentos de compactação foram: $\mathrm{T}_{0}=$ sem tráfego; $\mathrm{T}_{1^{*}}=1$ passada de trator de $4 \mathrm{t}$; e, $\mathrm{T}_{1}$, $\mathrm{T}_{2}, \mathrm{~T}_{4}$ e $\mathrm{T}_{6}$, respectivamente, para 1, 2, 4 e 6 passadas de um trator de $11 \mathrm{t}$, no mesmo local, uma ao lado da outra. Após a compactação foi semeado o cultivar de soja (Glycine max) MG/BR 46 (Conquista).O delineamento experimental foi inteiramente casualizado, com seis níveis de compactação e quatro repetições (parcelas de $9,0 \mathrm{~m}^{2}$ ). Foram coletadas amostras indeformadas de solo nas camadas de 0,030,$06 ; 0,08-0,11 ; 0,15-0,18$ e $0,22-0,25 \mathrm{~m}$, para determinação dos atributos físicos. As raízes foram avaliadas nas camadas de $0,0-0,10 ; 0,10-0,15$ e $0,20-0,25$ m. A compactação do solo diminuiu o desenvolvimento radicular em profundidade e não alterou a quantidade total de raízes, apenas sua distribuição. A produtividade de soja decresceu a partir da resistência do solo à penetração de 2,33 $\mathrm{MPa}$ e da densidade do solo de $1,51 \mathrm{Mg} \mathrm{m}^{-3}$.

Palavras-chave: Glycine max, tráfego de máquinas, densidade do solo, resistência à penetração
\end{abstract}

\section{INTRODUCTION}

Compaction changes soil structure, increases mechanical impediment to root development and decreases total porosity, macroporosity, water and nutrient availability and gas diffusion in soils (Taylor \&
Brar, 1991). Consequently, root development is affected and a lower soil volume is explored. In general, roots cannot penetrate compacted soil layers, inhibiting elongation of pivotal roots and increasing growth of thin lateral roots in smaller compacted layers (Materechera et al., 1992). 
Root morphological alterations often take place superficially in compacted soils, reducing root length (Yamaguchi \& Tanaka, 1989; Pabin et al., 1998), or even redistributing roots to less compacted layers, which decrease the distance among roots (Lipiec et al., 1991; Bouwman \& Arts, 2000; Rosolem et al., 2002; Beutler \& Centurion, 2004). These changes can reduce both water use and nutrient absorption by roots which has a linear correlation with shoot dry mass accumulation (Lipiec et al., 1993).

Brazil is the $2^{\text {nd }}$ largest soybean producer, USA being the $1^{\text {st }}$ worldwide (Agrianual, 2006). Many farmers prefer the conventional or minimum tillage cropping systems because they loosen the soil and becomes soft (Carter et al., 1991). These systems promote greater porosity, water infiltration and lower mechanic strength for root growth (Carter et al., 1991). On the other hand, it has been shown that small levels of soil compaction may increase yield. This compaction usually occurs in no-tillage cropping systems, which allow a better environmental preservation in comparison to conventional systems, that for this reason are more and more prefered in Brazil. Machinery traffic with excessive weight or under conditions of high soil water content may promote excessive soil compaction in no-tillage systems, especially in top layers, reducing plant root growth and yield.

This study was carried out to evaluate both root development and soybean yield in an Oxisol field under compaction levels.

\section{MATERIAL AND METHODS}

The experiment was carried out in Jaboticabal, State of São Paulo, Brazil $\left(21^{\circ} 15^{\prime}\right.$ S, 48 ${ }^{\circ} 16^{\prime}$ W; 600 $\mathrm{m}$ above sea level). The climate is of the Cwa type, with moderate temperatures and hot and rainy summer, according to the classification system of KoppenGeiger. Precipitation data during the soybean growing season is shown in Figure 1.

The soil is a Typic Oxisol, with particle size distribution of the $0.0-0.20 \mathrm{~m}$ layer (clay, $330 \mathrm{~g} \mathrm{~kg}^{-1}$; silt, $35 \mathrm{~g} \mathrm{~kg}^{-1}$ and sand $635 \mathrm{~g} \mathrm{~kg}^{-1}$ ) determined by $\mathrm{NaOH}$ $\left(0.1 \mathrm{~mol} \mathrm{~L}^{-1}\right)$ dispersion and the pipette method; particle density determined by the pycnometer method (2.72 $\mathrm{Mg} \mathrm{m}^{-3}$ ); chemical characteristics determined as recommended by Raij et al. (1987) shown in Table 1.

The experiment was arranged in a completely randomized design, with six compaction levels and four replicates. Plot area was $9.0 \mathrm{~m}^{2}$ with a useful area of $3.37 \mathrm{~m}^{2}$.

In November 2004, the soil was subsoiled to a $0.30 \mathrm{~m}$ depth and leveled with one harrowing. After one precipitation, when the water content was around field capacity (gravimetric water content of $0.14 \mathrm{~kg} \mathrm{~kg}^{-1}$, $0.01 \mathrm{MPa}$ ), compaction treatments were performed: $\mathrm{T}_{0}$ $=$ no traffic; $\mathrm{T}_{1^{*}}=$ one passage of a $4 \mathrm{t}$ tractor; $\mathrm{T}_{1}, \mathrm{~T}_{2}$, $\mathrm{T}_{4}$ and $\mathrm{T}_{6}$, for $1,2,4$ and 6 passages, respectively, of a $11 \mathrm{t}$ tractor, with four tires of the same width $(0.40$ $\mathrm{m})$. Compactions were performed each besides the other, towards the slope, over the entire soil surface.

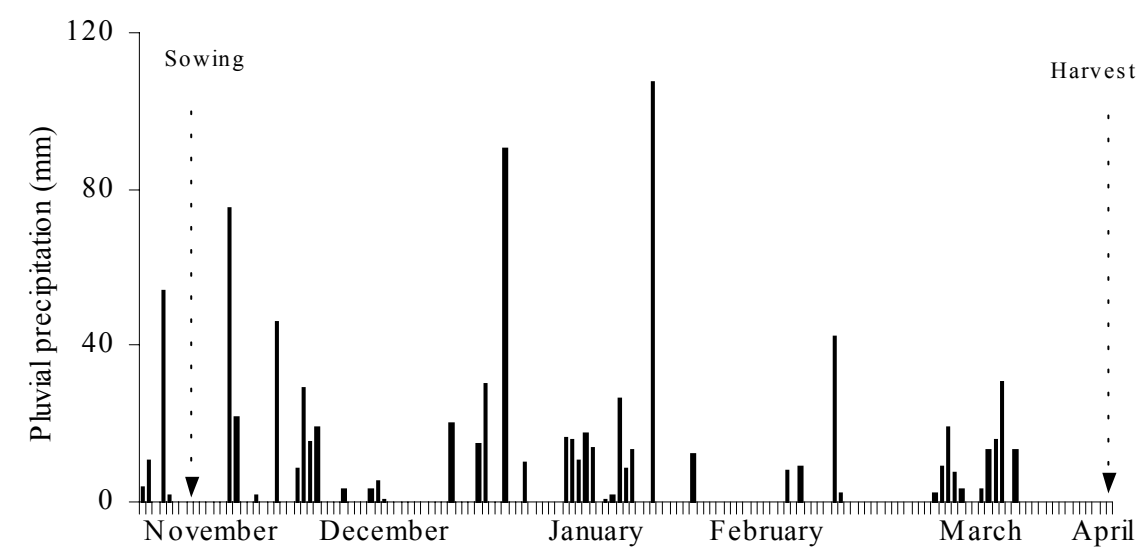

Figure 1 - Daily rainfall during the soybean growing season (2004/05).

Table 1 - Means $(n=10)$ of soil chemical characteristics before fertilization.

\begin{tabular}{|c|c|c|c|c|c|c|c|c|}
\hline Layer & $\begin{array}{c}\mathrm{pH} \mathrm{CaCl} \\
0.01 \mathrm{~mol} \mathrm{~L}^{-1}\end{array}$ & $\begin{array}{c}\text { Organic } \\
\text { matter }\end{array}$ & $\mathrm{P}_{\text {resin }}$ & K & $\mathrm{Ca}$ & M & $\mathrm{H}+\mathrm{Al}$ & $\begin{array}{c}\text { Basis } \\
\text { saturation }\end{array}$ \\
\hline $\mathrm{m}$ & & $\mathrm{g} \mathrm{dm}^{-3}$ & $\mathrm{mg} \mathrm{dm}{ }^{-3}$ & $-\cdots-\cdots$ & $\cdots n$ & $m^{-3}$ & 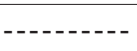 & $\%$ \\
\hline $0.0-0.1$ & 5.8 & 15 & 30 & 2.2 & 22 & 1 & 17 & 73 \\
\hline $0.1-0.2$ & 5.1 & 14 & 17 & 2.2 & 17 & 1 & 23 & 58 \\
\hline
\end{tabular}


On November $22^{\text {nd }}, 2004$, soybean [Glycine $\max \mathrm{cv}$. MG/BR 46 (Conquista)] seeds were inoculated with Bradyrhizobium japonicum and sown to the 0.05 $\mathrm{m}$ depth, with $0.45 \mathrm{~m}$ row spacing, transversely to the tractor traffic and slope. Two $20 \mathrm{~mm}$ sprinkler irrigations were applied after sowing to allow seed germination. Ten days later, a thinning was performed leaving 20 plants per row meter. The fertilization was performed at sowing to reach an expected grain yield of 3.5 to $4.0 \mathrm{t} \mathrm{ha}^{-1}$, according to Raij et al. (1996).

In December, two sample groups (replicates) were collected with metal cilinders $0.03 \mathrm{~m}$ high and $0.048 \mathrm{~m}$ diameter $\left(53.16 \times 10^{-6} \mathrm{~m}^{3}\right)$, in the $0.03-0.06$, $0.08-0.11,0.15-0.18$ and $0.22-0.25 \mathrm{~m}$ layers, to evaluate physical properties. One sample of each group was saturated for $24 \mathrm{~h}$, submitted to tensions of 0.006 or $0.010 \mathrm{MPa}$ in Richard's pressure chambers with porous plates (Klute, 1986). Samples submitted to $0.010 \mathrm{MPa}$ tension were used to measure the resistance to penetration (RP), with two replicates per sample. The RP of each replication was read 100 times to calculate a mean RP (Leão \& Silva, 2006). RP was determined with a static, electronic penetrometer, with a cone semi-angle of $30^{\circ}$, constant penetration speed of $0.01 \mathrm{~m} \mathrm{~min}^{-1}$, cone base area of $2.96 \times 10^{-6} \mathrm{~m}^{2}$, and equipped with a linear actuator and a charge cell of $20 \mathrm{~kg}$, attached to a computer for data acquisition. The cone base diameter was $0.00194 \mathrm{~m}, 24.7$ times smaller than the soil sample diameter, avoiding lateral confinement of the soil sample when resistance to penetration was determined, according to Fritton (1990).

Samples were then dried at $\pm 105^{\circ} \mathrm{C}$ until constant weight for water content determination at each tension and soil bulk density $\left(\mathrm{D}_{\mathrm{b}}\right)$ measurement (Blake $\&$ Hartge, 1986). Microporosity was taken as the water content at tension of $0.006 \mathrm{MPa}$ (pores $<50 \mu \mathrm{m}$ ), according to Danielson \& Sutherland (1986), while the macroporosity (pores $>50 \mu \mathrm{m}$ ) was taken by difference.

At the R6 growth stage (grain filling) of the scale proposed by Fehr et al. (1971), soil samples of $0.10 \mathrm{~m}$ length $\times 0.10 \mathrm{~m}$ width were taken from rows, at both sides of the plant, with metal boxes (Figure 2 ), in the $0.0-0.10 ; 0.10-0.15$ and $0.20-0.25 \mathrm{~m}$ layers. Roots were then separated from the soil by washing with tap water on a sieve of $0.053 \mathrm{~mm}$ mesh. Subsequently, roots were spread over a tray with water and their digital pictures were taken with an optical scanner (Hewlett Packard 5C ${ }^{\circledR}$ ) at 400 dpi resolution. Root diameter, density and surface area were analyzed using the software Delta-T Scan ${ }^{\circledR}$, based on the method proposed by Harris \& Campbell (1989). Roots were then dried at $\pm 65^{\circ} \mathrm{C}$ until constant weight for dry mass determination.

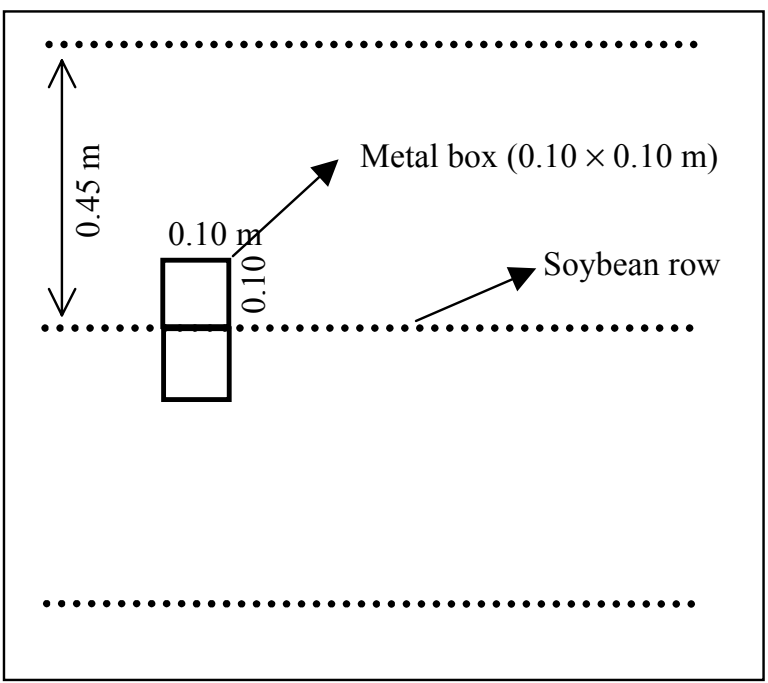

Figure 2 - Soil sample collection scheme for evaluation of the soybean root system, in the layers of $0.0-0.10,0.10-$ 0.15 and $0.20-0.25 \mathrm{~m}$.

At soybean bloom, sixteen sub-samples were collected of the third or fourth leaflets from plant apex, including the petiole, to determine shoot nutrient, according to Bataglia et al. (1983). Grain yield was determined for an area of $3.37 \mathrm{~m}^{2}$ and the yield per hectare was then calculated.

Data were submitted to ANOVA using the $\mathrm{F}$ test $(P<0.05)$. When significant, polynomial regressions were fitted between RP and root development parameters, grain yield, and between $\mathrm{D}_{\mathrm{b}}$ and grain yield.

\section{RESULTS AND DISCUSSION}

Tractor traffic caused soil compaction, which reduced macropores, and increased $D_{b}$ and RP from loose to very compacted soil $\left(\mathrm{T}_{0}-\mathrm{T}_{6}\right)$ (Table 2$)$. The micropores increased slightly from $\mathrm{T}_{0}-\mathrm{T}_{1}$, not being modified from $\mathrm{T}_{1^{*}}-\mathrm{T}_{6}$. At the $0.22-0.25 \mathrm{~m}$ layer, $\mathrm{D}_{\mathrm{b}}$ and RP were little affected. Their values however were close to the limits of $1.62 \mathrm{Mg} \mathrm{m}^{-3}$ (Dexter, 2004) and $1.48 \mathrm{Mg} \mathrm{m}^{-3}$ (Beutler et al., 2005) for soils of similar clay content, and 2.0 to 3.0 MPa for RP, from which soybean yield starts to decrease (Barber, 1994).

The excessive soil compaction caused by tractor traffic affected root development and decreased grain yield $\left(\mathrm{T}_{1^{*}}-\mathrm{T}_{6}\right)(P<0.05$; Tables 2 and 3 ; Figures 3, 4 and 5). Compaction neither influenced root diameter, density, surface nor dry mass. However, it did affect root distribution in depth, which is in agreement with Rosolem et al. (2002).

Root density, surface and dry mass were greater at the top soil layer $(0.0-0.10 \mathrm{~m})$ with compaction increasing $\left(\mathrm{T}_{0}-\mathrm{T}_{6}\right),(P<0.05$; Figures 3 and 4). In $T_{6}$ almost all roots were concentrated in the 
Table 2 - Mean values of soil physical attributes of layers submitted to different tractor passages.

\begin{tabular}{|c|c|c|c|c|c|c|c|}
\hline \multirow{2}{*}{$\begin{array}{l}\text { Physical } \\
\text { attributes }\end{array}$} & \multirow{2}{*}{$\begin{array}{l}\text { Layer } \\
(\mathrm{m})\end{array}$} & \multicolumn{6}{|c|}{${ }^{\mathrm{a}}$ Tractor passages } \\
\hline & & $\mathrm{T}_{0}$ & $\mathrm{~T}_{1 *}$ & $\mathrm{~T}_{1}$ & $\mathrm{~T}_{2}$ & $\mathrm{~T}_{4}$ & $\mathrm{~T}_{6}$ \\
\hline \multirow{4}{*}{$\begin{array}{l}\text { Macroporosity } \\
\left(\mathrm{m}^{3} \mathrm{~m}^{-3}\right)\end{array}$} & $0.03-0.06$ & ${ }^{\mathrm{b}} 0.26 \pm 0.00$ & $0.09 \pm 0.01$ & $0.07 \pm 0.01$ & $0.05 \pm 0.01$ & $0.05 \pm 0.01$ & $0.03 \pm 0.01$ \\
\hline & $0.08-0.11$ & $0.22 \pm 0.00$ & $0.07 \pm 0.01$ & $0.07 \pm 0.01$ & $0.07 \pm 0.00$ & $0.05 \pm 0.01$ & $0.05 \pm 0.00$ \\
\hline & $0.15-0.18$ & $0.18 \pm 0.06$ & $0.10 \pm 0.01$ & $0.08 \pm 0.01$ & $0.08 \pm 0.01$ & $0.07 \pm 0.00$ & $0.07 \pm 0.01$ \\
\hline & $0.22-0.25$ & 0.18 & 0.11 & 0.08 & 0.08 & 0.08 & 0.08 \\
\hline \multirow{4}{*}{$\begin{array}{l}\text { Microporosity } \\
\left(\mathrm{m}^{3} \mathrm{~m}^{-3}\right)\end{array}$} & $0.03-0.06$ & $0.26 \pm 0.00$ & $0.30 \pm 0.00$ & $0.30 \pm 0.01$ & $0.29 \pm 0.01$ & $0.28 \pm 0.01$ & $0.29 \pm 0.00$ \\
\hline & $0.08-0.11$ & $0.27 \pm 0.00$ & $0.29 \pm 0.01$ & $0.30 \pm 0.01$ & $0.28 \pm 0.01$ & $0.30 \pm 0.01$ & $0.29 \pm 0.01$ \\
\hline & $0.15-0.18$ & $0.28 \pm 0.02$ & $0.29 \pm 0.01$ & $0.30 \pm 0.01$ & $0.29 \pm 0.01$ & $0.29 \pm 0.00$ & $0.29 \pm 0.00$ \\
\hline & $0.22-0.25$ & 0.27 & 0.29 & 0.31 & 0.30 & 0.30 & 0.31 \\
\hline \multirow{4}{*}{$\begin{array}{l}\text { Soil bulk } \\
\text { density } \\
\left(\mathrm{Mg} \mathrm{m}^{-3}\right)\end{array}$} & $0.03-0.06$ & $1.24 \pm 0.02$ & $1.58 \pm 0.01$ & $1.67 \pm 0.01$ & $1.75 \pm 0.02$ & $1.79 \pm 0.01$ & $1.81 \pm 0.01$ \\
\hline & $0.08-0.11$ & $1.32 \pm 0.02$ & $1.66 \pm 0.01$ & $1.66 \pm 0.01$ & $1.71 \pm 0.01$ & $1.74 \pm 0.01$ & $1.75 \pm 0.01$ \\
\hline & $0.15-0.18$ & $1.41 \pm 0.02$ & $1.62 \pm 0.01$ & $1.64 \pm 0.01$ & $1.67 \pm 0.01$ & $1.68 \pm 0.01$ & $1.69 \pm 0.01$ \\
\hline & $0.22-0.25$ & 1.42 & 1.57 & 1.62 & 1.63 & 1.59 & 1.56 \\
\hline \multirow{4}{*}{$\begin{array}{l}\text { Resistance to } \\
\text { penetration } \\
(\mathrm{MPa})\end{array}$} & $0.03-0.06$ & $0.83 \pm 0.13$ & $2.07 \pm 0.02$ & $2.71 \pm 0.09$ & $3.57 \pm 0.32$ & $5.03 \pm 0.01$ & $6.75 \pm 1.52$ \\
\hline & $0.08-0.11$ & $1.23 \pm 0.44$ & $2.38 \pm 0.03$ & $2.15 \pm 0.04$ & $2.75 \pm 0.23$ & $3.99 \pm 0.23$ & $4.62 \pm 0.10$ \\
\hline & $0.15-0.18$ & $1.43 \pm 0.40$ & $2.17 \pm 0.14$ & $2.23 \pm 0.02$ & $3.01 \pm 1.10$ & $3.02 \pm 0.49$ & $3.06 \pm 0.49$ \\
\hline & $0.22-0.25$ & 1.08 & 1.96 & 1.71 & 2.36 & 2.68 & 2.48 \\
\hline
\end{tabular}

${ }^{a} \mathrm{~T}_{0}, \mathrm{~T}_{1}, \mathrm{~T}_{2}, \mathrm{~T}_{4}$ and $\mathrm{T}_{6}$, respectively, for $0,1,2,4$ and 6 passages of an $11 \mathrm{t}$ tractor at the same place, on the water content at the field capacity (tension of $0.01 \mathrm{MPa}$ ). In $\mathrm{T}_{1 *}$ a $4 \mathrm{t}$ tractor was used. ${ }^{\mathrm{b}}$ Mean + standard error. $(n=2$ for macro and microporosity and resistance to penetration; $n=12$ for soil bulk density).

Table 3 - ANOVA for compaction levels: root development parameters and grain yield.

\begin{tabular}{lcc}
\hline Parameters & Layer $(\mathrm{m})$ & $F$-Value \\
\hline \multirow{3}{*}{ Root diameter } & $0.0-0.10$ & $1.11^{\mathrm{ns}}$ \\
& $0.10-0.15$ & $0.72^{\mathrm{ns}}$ \\
& $0.20-0.25$ & $3.46^{\mathrm{ns}}$ \\
\hline \multirow{3}{*}{ Root density } & $0.0-0.10$ & $4.49^{* *}$ \\
& $0.10-0.15$ & $9.96^{* *}$ \\
\hline \multirow{3}{*}{ Root surface } & $0.20-0.25$ & $251.29^{* *}$ \\
\hline & $0.0-0.10$ & $3.01^{*}$ \\
\hline \multirow{3}{*}{ Root dry mass } & $0.10-0.15$ & $93.03^{*}$ \\
& $0.20-0.25$ & $5.79^{*}$ \\
\hline Grain yield & $0.0-0.10$ & $4.24^{*}$ \\
\hline
\end{tabular}

ns,,${ }^{* *}$ Non significant, significant at 5 and $1 \%$, respectively.

loosen soil in row originated during sowing, because of the high compaction level of this treatment, which limited root growth in depth, as observed by Busscher et al. (2000). In general, in compacted layers roots respond with both thickening and deflection (Materechera et al., 1992), therefore, thicker roots produce higher axial pressure and are most efficient in penetrating soil compacted layers (Misra et al., 1986).
When compaction is excessive it reduces root penetration, and lateral roots are produced in less compacted layers (Materechera et al., 1992), as in $T_{1^{*}}-T_{6}$. The compensation depends on the compaction level and water availability (Busscher et al., 2000). For this reason, roots were closer to each other in the $0.0-0.10$ $\mathrm{m}$ layer, and more distant in greater layers, which confirm the results observed by Lipiec et al. (1991), Bouwman \& Arts (2000) and Rosolem et al. (2002).

This superficial root concentration in compacted soils $\left(\mathrm{T}_{1^{*}}-\mathrm{T}_{6}\right)$ is shown in transversal row cuts (Figure 4). In compacted soil, the roots near to the main root were thickened in top $\left(\mathrm{T}_{2}\right.$ and $\mathrm{T}_{6}$; Figure 4$)$, and could not be identified by the mean root diameter (Figure 3). This is because of a greater concentration of thin roots in the top layer of compacted soils, diluting the higher diameter of $T_{2}-T_{6}$ to a mean diameter similar to the soft soil $\left(\mathrm{T}_{0}\right)$, according to Mckenzie et al. (2001) and Iijima et al. (2000). Also in a soybean experiment, Rosolem \& Takahashi (1998) observed higher root diameters when RP $>1.2 \mathrm{MPa}$.

In the $0.0-0.10 \mathrm{~m}$ layer of the compacted soil, greater root density and surface were observed. At 0.22 to $0.25 \mathrm{~m}$, just a small increase of root growth occured until a RP of $1.80 \mathrm{MPa}$, which decreased for a greater RP, because roots compensate the lower growth in the compacted layer, in the less compacted layers of 0.22 to $0.25 \mathrm{~m}$ and in the top layer, accord- 

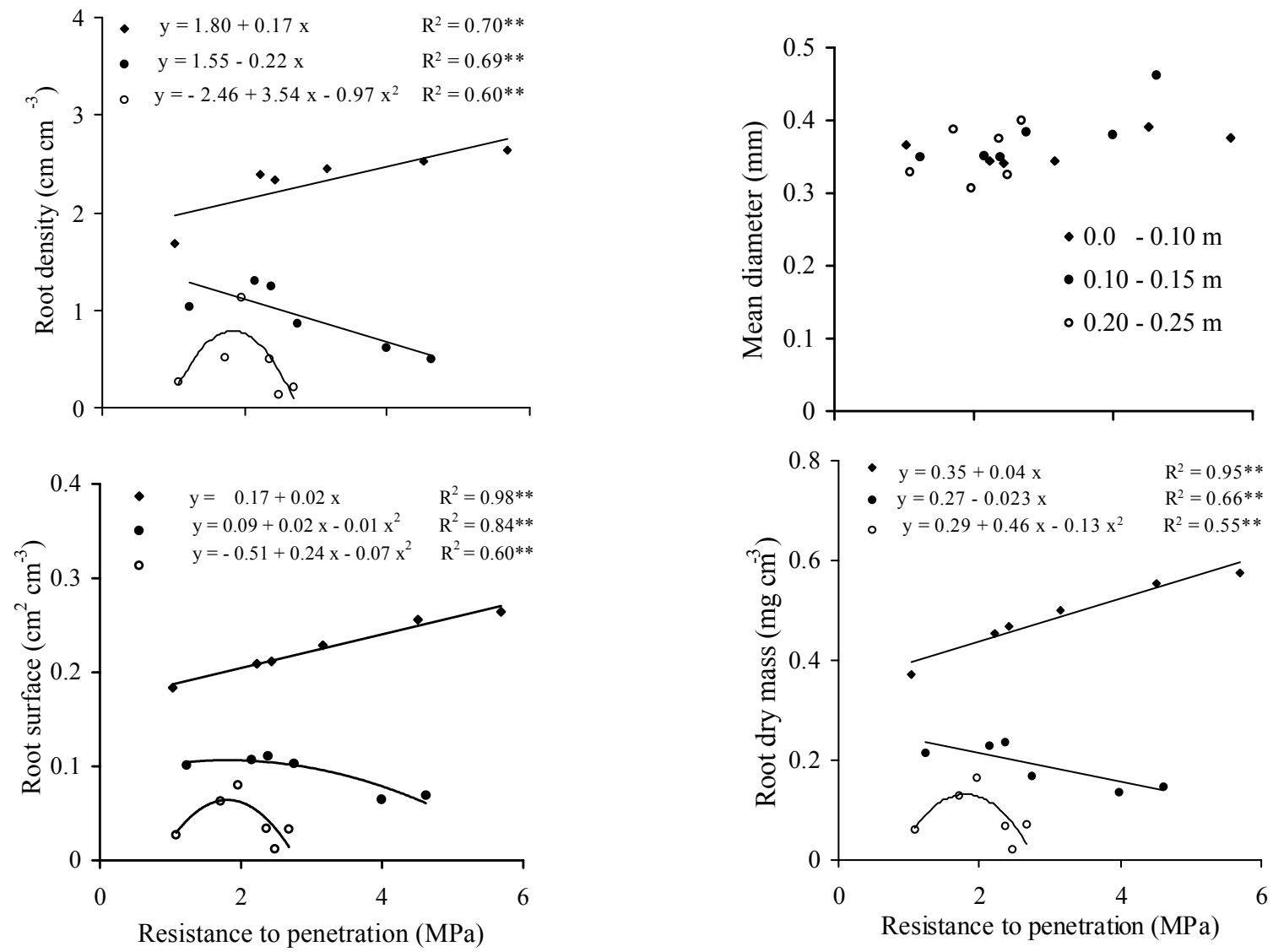

Figure 3 - Regressions between root development parameters and soil resistance to penetration (means). **ANOVA ( $F$-Values) significant at $P<0.01$. Layer of 0.0-0.10 ( $\bullet, 0.10-0.15(\bullet)$ and $0.20-0.25 \mathrm{~m}(\mathrm{O})$.

ing to Busscher et al. (2000). After RP of $1.80 \mathrm{MPa}$, the vertical pressure exerted by roots was not enough to penetrate into the intermediate compacted layer, resulting in growth decrease at the deeper layer of 0.22 $-0.25 \mathrm{~m}$.

In compacted soils grow smaller and deeper roots, so that their length is not altered. Their distribution is changed, according to Bouwman \& Arts (2000), Rosolem et al. (2002) and Beutler \& Centurion (2004), without decreasing the total amount of roots, as observed in other crops (Yamaguchi \& Tanaka, 1989; Lipiec et al., 1993; Pabim et al., 1998). Therefore, soybean roots explore less soil and consequently absorb less water and nutrients, often not enough to supply shoot demands and to allow maximum yield. In this case, root growth concentrates within the sowing row, reducing nutrient absorption in deeper layers. Also, water evaporation is faster at the top layer, which usually has lower water availability in comparison to deeper layers (Beutler \& Centurion, 2004). It may cause insufficient water absorption to sustain adequate soybean growth, resulting in yield decrease, as observed in this study $\left(T_{1}-T_{6}\right)($ Fig- ure 5), as a result of several days without rain, exposing roots to frequent water deficit over the soybean season (Figure 1). It seems reasonable, since previous studies have shown that the absorption of water and nutrients takes place near to root surface at distances shorter than $2-8 \mathrm{~mm}$ depending on the soil (Yamaguchi \& Tanaka, 1989). In cases of both irrigated soil and well drained, root deformations are not responsible for yield losses (Mckenzie et al., 2001).

To determine if nutrient deficiency has occurred in shoots due to soil compaction, nutrient levels were determined in soybean leaves. The results show no difference between compaction levels (Table 4). Thus, it can be assumed that the grain yield decrease in compacted soils is due to water deficit, which was evident in December, February and March 2005 (Figure 1). Plant physiology studies indicate there are other physiological factors involved. For example, when roots grow in compacted soil the abscisic acid's (ABA) production is increased in roots. ABA is then sent to shoots as a hormonal message (Masle \& Passioura, 1987; Mulholland et al., 1996). In response, 

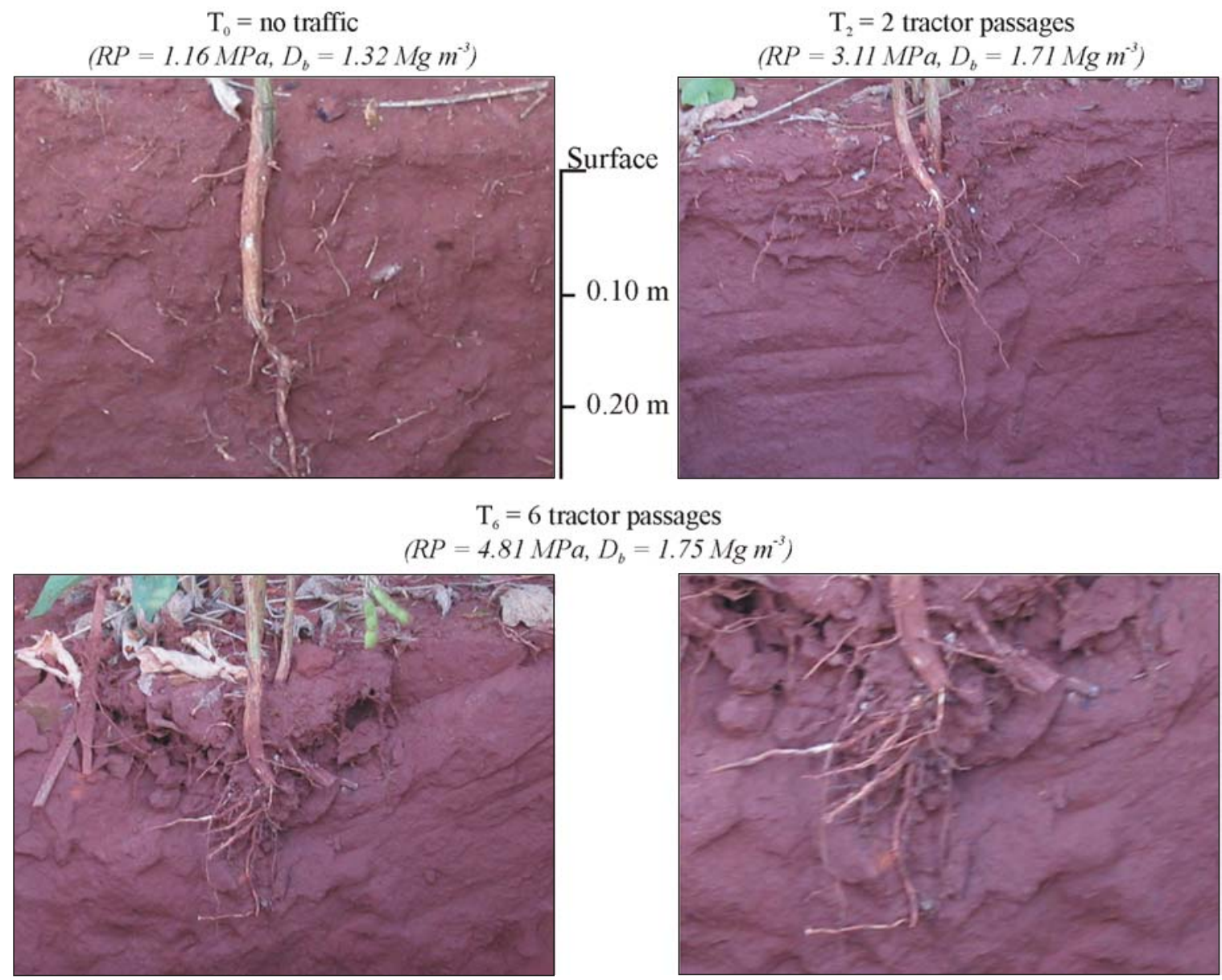

$$
\left.a, D_{b}=1.75 \mathrm{Mg} \mathrm{m}^{-3}\right)
$$

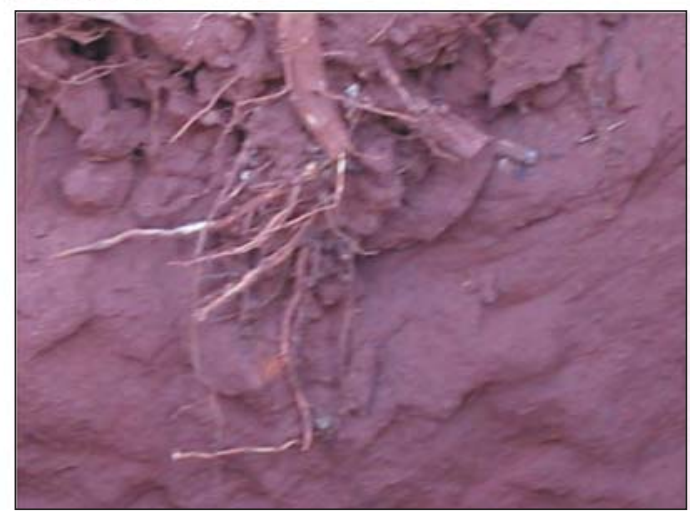

Figure 4 - Soybean root development profile ( $0.25 \mathrm{~m}$ depth), transversely to the row, under different passage numbers of an $11 \mathrm{t}$ tractor. $R P$, resistance to penetration; $D_{b}$, soil bulk density $(0.0-0.20 \mathrm{~m})$.

Table 4 - Means for nutrient levels in soybean leaves, under different compaction levels.

\begin{tabular}{lccccccccc}
\hline $\begin{array}{l}\text { Tractor } \\
\text { passages }\end{array}$ & ${ }^{\mathrm{b}} \mathrm{N}$ & $\mathrm{P}$ & $\mathrm{K}$ & $\mathrm{Ca}$ & $\mathrm{Mg}$ & $\mathrm{S}$ & $\mathrm{B}$ & $\mathrm{Cu}$ & $\mathrm{Fe}$ \\
\hline & - & & & & & \\
${ }^{\mathrm{a}} \mathrm{T}_{0}$ & 48 & 3.2 & 24 & 7.8 & 4.7 & 2.9 & 34 & 7.0 & 100 \\
$\mathrm{~T}_{1 *}$ & 46 & 3.3 & 23 & 7.9 & 4.5 & 2.8 & 33 & 7.0 & 106 \\
$\mathrm{~T}_{1}$ & 48 & 3.4 & 23 & 7.8 & 4.5 & 2.9 & 34 & 9.5 & 129 \\
$\mathrm{~T}_{2}$ & 35 & 3.3 & 25 & 8.4 & 4.2 & 2.9 & 32 & 8.0 & 90 \\
$\mathrm{~T}_{4}$ & 47 & 3.2 & 24 & 7.7 & 4.1 & 2.7 & 34 & 6.5 & 90 \\
$\mathrm{~T}_{6}$ & 46 & 3.2 & 27 & 7.9 & 4.2 & 2.7 & 34 & 6.0 & 96 \\
\hline
\end{tabular}

a $\mathrm{T}_{0}, \mathrm{~T}_{1}, \mathrm{~T}_{2}, \mathrm{~T}_{4}$ and $\mathrm{T}_{6}$, respectively, for $0,1,2,4$ and 6 passages of an $11 \mathrm{t}$ tractor, at the same place, on the water content at the field capacity $(0.01 \mathrm{MPa})$. In $\mathrm{T}_{1^{*}}$ a $4 \mathrm{t}$ tractor was used. ${ }^{\mathrm{b}}$ There was no difference for nutrient levels in shoots between compaction levels $(P<0.05)$.

stomatal conductance is reduced, as well as photosynthesis and leaf expansion (Davies et al., 1994), reducing plant growth. Also, root carbohydrate demands increase, resulting in lower carbon allocation to shoots (Tubeileh et al., 2003).

In the soft soil (no traffic, $\mathrm{T}_{0}$ ), roots were distributed more uniformly and deeply in the profile, exploring more soil volume and water at deeper layers.
The greater soybean yield was reached in slightly compacted soil (Figure 5), possibly because of higher rootsoil contact, allowing greater water and nutrient uptake (Kooistra et al., 1992).

At RP and $\mathrm{D}_{\mathrm{b}}$ values of $2.33 \mathrm{MPa}$ and 1.51 $\mathrm{Mg} \mathrm{m}^{-3}$, respectively, grain yield began to decrease. This RP is close to 2.0 MPa, which is adopted as a critical value for root growing (Taylor et al., 1966) and 

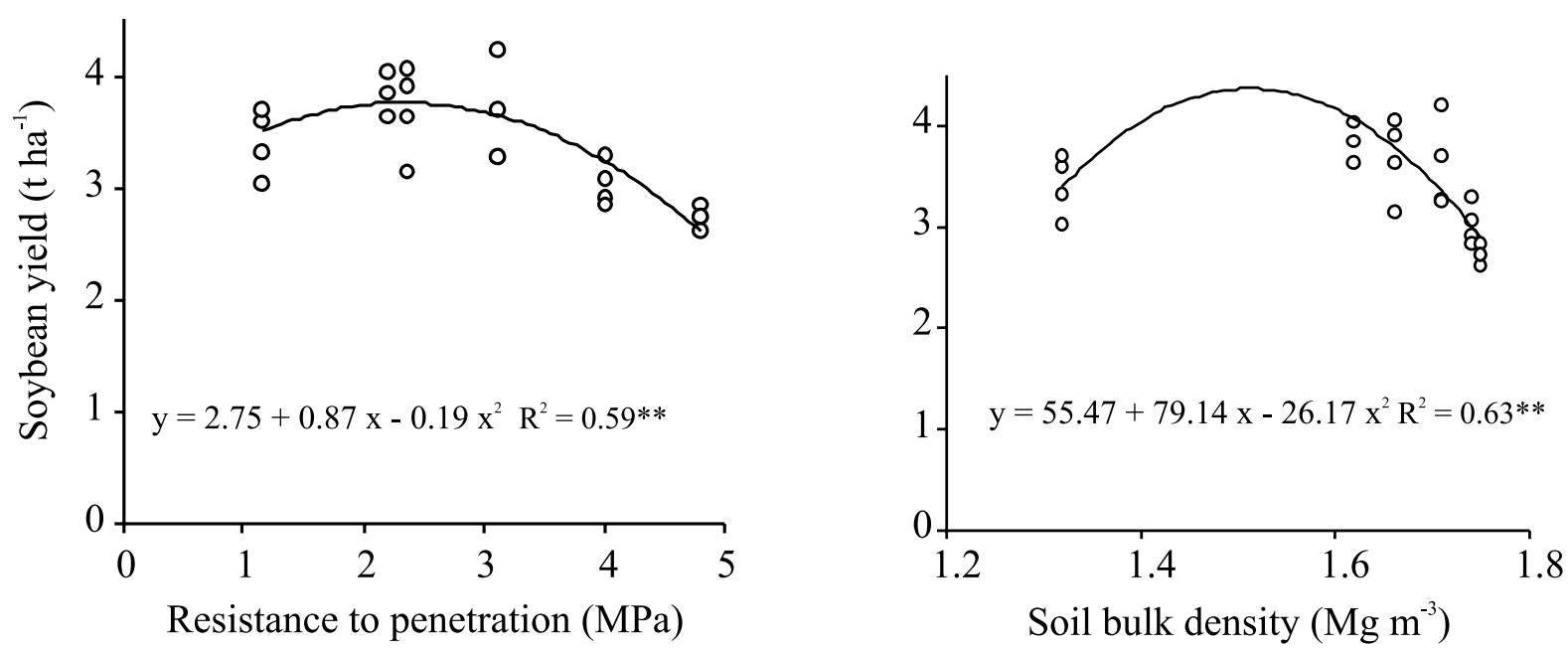

Figure 5 - Soybean yield as a function of soil resistance to penetration and soil bulk density (means).**ANOVA ( $F$-Values) significant at $P<0.01$.

between 2.0 and 3.0 MPa as limiting values for soybean yield, according to Barber (1994), in tropical soils. The $\mathrm{D}_{\mathrm{b}}$ is similar to the $1.48 \mathrm{Mg} \mathrm{m}^{-3}$ found in the soybean season 2003/04 in the same place (Beutler et al., 2005) and lower than $1.62 \mathrm{Mg} \mathrm{m}^{-3}$, presented in Dexter's root growth diagram, for soils with similar clay levels (Dexter, 2004).

Soil compaction by machinery traffic did not affect the total amount of roots, but their spatial distribution leading to soybean yield decreasing at PR of $2.33 \mathrm{MPa}$ and $\mathrm{D}_{\mathrm{b}}$ of $1.51 \mathrm{Mg} \mathrm{m}^{-3}$.

\section{ACKNOWLEDGMENTS}

To FAPESP, CNPq and CAPES for fellowships.

\section{REFERENCES}

AGRIANUAL 2006: Anuário da agricultura brasileira. São Paulo: FNP Consultoria e Comércio, 2006. p.433-468.

BARBER, R.G. Persistence of loosened horizons and soybean yield increases in Bolivia. Soil Science Society of American Journal, v.58, p.943-950, 1994.

BATAGLIA, O.C.; FURLANI, A.M.C.; TEIXEIRA, J.P.F.; FURLANI, P.R.; GALLO, J.R. Métodos de análise química das plantas. Campinas: Instituto Agronômico, 1983. 48p. (Boletim Técnico, 78).

BEUTLER, A.N.; CENTURION, J.F. Compactação do solo no desenvolvimento radicular e na produtividade da soja. Pesquisa Agropecuária Brasileira, v.39, p.581-588, 2004.

BEUTLER, A.N.; CENTURION, J.F.; SILVA, A.P. Soil resistance to penetration and least limiting water range for soybean yield in a haplustox from Brazil. Brazilian Archives of Biology and Technology, v.48, p.863-871, 2005.

BLAKE, G.R.; HARTGE, K.H. Bulk density. In: KLUTE, A. (Ed.). Methods of soil analysis: physical and mineralogical methods. 2.ed. Madison: ASA, 1986. p.363-375.

BOUWMAN, L.A.; ARTS, W.B.M. Effects of soil compaction on the relationships between nematodes, grass production and soil physical properties. Applied Soil Ecology, v.14, p.213-222, 2000 .
BUSSCHER, W.J.; FREDERICK, J.R.; BAUER, P.J. Timing effects of deep tillage on penetration resistance and wheat and soybean yield. Soil Science Society of American Journal, v.64, p.999-1003, 2000.

CARTER, L.M.; MEEK, B.D.; RECHEL, E.A. Zone production system for cotton, soil response. Transactions of the ASAE, v.34, p.354-360, 1991 .

DANIELSON, R.E.; SUTHERLAND, P.L. Porosity. In: KLUTE, A. (Ed.). Methods of soil analysis: physical and mineralogical methods. 2.ed. Madison: ASA, 1986. p.443-461.

DAVIES, W.J.; TARDIEU, F.; TREJO, C.L. How do chemical signals work in plants that grow in drying soil? Plant Physiology, v.104, p.309-314, 1994.

DEXTER, A.R. Soil physical quality: Part I. Theory, effects of soil texture, density, and organic matter, and effects on root growth. Geoderma, v.120, p.201-214, 2004.

FEHR, W.R.; GAVINESS, C.E.; BURMOOD, D.T.; PENNINGTON, J.S. Stage of development description for soybeans (Glycine $\max (\mathrm{L})$ Merrill). Crop Science, v.11, p.929-931, 1971.

FRITTON, D.D. A standard for interpreting soil penetrometer measurements. Soil Science, v.150, p.542-551, 1990.

HARRIS, G.A.; CAMPBELL, G.S. Automated quantification of roots using a simple image analyzer. Agronomy Journal, v.81, p.935-938, 1989 .

IIJIMA, M.; GRIFFITHS, B.; BENGOUGH, A.G. Sloughing of cap cells and carbon exudation from maize seedling roots in compacted sand. New Phytologist, v.145, p.477-482, 2000.

LEÃO, T.P.; SILVA, A.P. A statistical basis for selecting parameters for the evaluation of soil penetration resistance. Scientia Agricola, v.63, p.552-557, 2006.

KLUTE, A. Water retention: laboratory methods. In: KLUTE, A. (Ed.). Methods of soil analysis: physical and mineralogical methods. 2.ed. Madison: ASA, 1986. p.635-662.

KOOISTRA, M.J.; SCHOONDERBEEK, D.; BOONE, F.R.; VEEN, B.W.; NOORDWIJK, M. VAN. Root-soil contact of maize, as measured by a thin-section technique - II: effects of soil compaction. Plant and Soil, v.139, p.119-129, 1992.

LIPIEC, J.; HÅKANSSON, I.; TARKIEWICZ, S.; KOSSOWSKI, J. Soil physical properties and growth of spring barley as related to the degree of compactness of two soils. Soil \& Tillage Research, v.19, p.307-317, 1991.

LIPIEC, J.; ISHIOKA, T.; HATANO, R.; SAKUMA, T. Effects of soil structural discontinuity on root and shoot growth and water use of maize. Plant and Soil, v.157, p.65-74, 1993. 
MASLE, A.; PASSIOURA, J.B. Effect of soil strength on the growth of young wheat plants. Australian Journal of Plant Physiology, v.14, p.643-656, 1987.

MATERECHERA, S.A.; ALSTON, A.M.; KIRBY, J.M.; DEXTER, A.R. Influence of root diameter on the penetration of seminal roots into a compacted subsoil. Plant and Soil, v.144, p.297303, 1992.

MCKENZIE, D.C.; GREENHALGH, S.E.; KOPPI, A.J.; MACLEOD, D.A.; MCBRATNEY, A.B. Cotton root growth in a compacted Vertisol (Grey Vertosol) II. Correlation with image analysis parameters. Australian Journal of Soil Research, v.39, p.1169-1181, 2001

MISRA, R.K.; DEXTER, A.R.; ALSTON, A.M. Penetration of soil aggregates of finite size. II. Plant roots. Plant and Soil, v.94, p.59-85, 1986.

MULHOLLAND, B.J.; BLACK, C.R.; TAYLOR, I.B.; ROBERTS, J.A.; LENTON, J.R. Effect of soil compaction on barley (Hordeum vulgare L.) growth. I. Possible role for ABA as a root-sourced chemical signal. Journal of Experimental Botany, v.47, p.539-549, 1996

PABIN, J.; LIPIEC, J.; WODEK, S. Critical soil bulk density and strength for pea seedling root growth as related to other soil factors. Soil \& Tillage Research, v.19, p.131-143, 1998.

RAIJ, B.; CANTARELLA, H.; QUAGGIO, J.H.; FURLANI, A.M.C. Recomendação de adubação e calagem para o estado de São Paulo. 2.ed. Campinas: Instituto Agronômico \& Fundação IAC, 1996. 285p.(Boletim Técnico, 100).
RAIJ, B.; QUAGGIO, J.A.; CANTARELLA, H.; FERREIRA, M.E.; LOPES, A.S.; BATAGLIA, O.C. Análise química do solo para fins de fertilidade. Campinas: Fundação Cargill, 1987. $170 \mathrm{p}$.

ROSOLEM, C.A.; TAKAHASHI, M. Soil compaction and soybean root growth. In: BOX JR. J.E. Root demographics and their efficiencies in sustainable agriculture, grasslands and forest ecosystems. Dordrecht: Kluwer Academic Publishers, 1998. p.295-304.

ROSOLEM, C.A.; FOLONI, J.S.S.; TIRITAN, C.S. Root growth and nutrient accumulation in cover crops as affected by soil compaction. Soil \& Tillage Research, v.65, p.109-115, 2002.

TAYLOR, H.M.; ROBERSON, G.M.; PARKER JR., J.J. Soil strength-root penetration relations for medium to coarsetextured soil materials. Soil Science, v.102, p.18-22, 1966.

TAYLOR, H.M.; BRAR, G.S. Effect of soil compaction on root development. Soil \& Tillage Research, v.19, p.111-119, 1991.

TUBEILEH, A.; GROLEAU-RENAUD, V.; PLANTUREUX, S.; GUCKERT, A. Effect of soil compaction on photosynthesis and carbon partitioning within a maize-soil system. Soil \& Tillage Research, v.71, p.151-161, 2003.

YAMAGUCHI, J.; TANAKA, A. Quantitative observation on the root system of various crops growing in the field. Soil Science and Plant Nutrition, v.36, p.483-493, 1989.

Received August 02, 2006

Accepted June 15, 2007 